\title{
Slovak National Council and (Un)Implemented Principles of Parliamentarism between 1944 and $1992^{1}$
}

\author{
prof. JUDr. PhDr. Tomáš GÁBRIŠ, PhD., LLM, MA
}

\begin{abstract}
The Slovak National Council (SNC) was the body, which assumed to concentrate supreme state powers in its regulation no. 1/1944, during an anti-Nazi uprising taking place in the end of the Second World War in the territory of Slovakia. This body had, however, not been directly elected until the year 1954. And even when it was to be finally elected in direct elections, these were strongly marked by a completely new approach of Communist Party and its ideology towards the role and importance of elections - limited only to prove the generally accepted leadership of the Party. As far as the SNC's activity is concerned, it kept decreasing in the first half of the researched period - both in quantity (with regard to the scope of its competence and the number of results - enacted laws), and quality (SNC was simple approving all proposals and bills without any debates). Only in the conditions of Czechoslovak federation since 1969, SNC regained some importance. In the first half of the researched period, the SNC also lost any control over its own executive body - the Board of Trustees, which was nominated by the Prague government. In 1960, the Board of Trustees was even completely abolished. Only since 1969, the national government replaced the former Board in its function of a supreme executive body for the territory of Slovakia. However, even then the idea of unified state power, which is not to be separated into different branches (legislature, executive, judiciary) led to an idea of cooperation between the supreme state bodies instead of their mutual control - since these were to follow the same goals - common interest in construction of communism. This special relationship between the supreme state bodies can only be understood through the prism of monopolist rule of the Communist Party, denying the true fulfillment of principles of parliamentarism in Slovakia up to 1989, which were then gradually reconstructed until disintegration of Czechoslovakia in 1992.
\end{abstract}

\section{Keywords}

parliamentarism, Slovak National Council, Czechoslovak Republic, Board of Trustees, Communism

1 The paper is a partial outcome of the project APVV-15-0349 "Indivíduum a spoločnost' - ich vzájomná reflexia $v$ historickom procese". 


\section{Introduction}

The contribution offers in its first part an overview of evolution of parliamentarism in the territory of Slovakia, closely connected with the evolution of the Slovak National Council (hereinafter referred to as SNC). In its second, analytical part, it draws on the first part in order to analyze the (mal)functioning of parliamentary system in the territory of Slovakia between 1944 and 1992 - pointing to a number of its peculiarities. Thereby, we shall observe a spiral development of parliamentary system in the territory of Slovakia between 1944 and 1992, in which era the periods of observations and violation of the principles of parliamentarism alternated. In particular, we shall compare the periods of 1944-1954 and 1986-1992, during which significant changes in the character of parliamentarism took place in Slovakia. These time periods are defined by the electoral periods of the SNC. Our main research question is that of the actual role of parliamentary bodies in the period of "popular democracy" and of the "actually existing socialism" in the Soviet bloc countries, using the example of Czechoslovakia. A secondary research question is that of "nationalism" present in Czechoslovakia and its constitutional and legal expression on the example of Slovakia as a part of Czechoslovakia. The hypothesis we postulate is that of particular development of parliamentarism under the rule of Communist Party, which could be regarded as malfunctioning, paralyzed parliamentarism in the first of the periods under review and, on the other hand, as a return to classical parliamentarism in the second period under review. At the same time, we shall examine the changes in the function, position and tasks of the SNC as a "national parliament" in its shift from a single body of all legislative, governmental and executive powers (1944-45) to attempts at true parliamentarism (1945-48), a period of a "façade" parliament (1948-1989), up to the return to standard parliamentarism since 1989. The main purpose of the study is thus to re-assess the role of parliaments under specific circumstances applicable in the "communist regime" countries in the second half of the 20th century.

\section{Parliamentarism and its development in Slovakia}

Parliamentarism in its classical form is the result of a special historical development taking place in England; in other countries around the world it is implemented with greater or lesser success and adaptation. ${ }^{2}$ Classical English parliamentarism thereby did not actually work on the basis of a strict separation of powers in the spirit of Montesquieu, but rather on the principle of a close interaction between legislative and executive powers. Government members namely sit in the parliament, and ministers are responsible to the Head of State. Such a form of parliamentarism did not and does not occur in Central Europe in pure form; instead, the idea of separation of powers and a system of checks and balances is traditionally being applied - in the territory of Slovakia this tradition reaches back to the interwar period of Czechoslovak Republic, considered to have been a prime example of parliamentary democracy in East-Central Europe. ${ }^{3}$

2 SELINGER, William: Parliamentarism: From Burke to Weber, Cambridge 2019

3 Cf. ORZOFF, Andrea: Battle for the Castle: The Myth of Czechoslovakia in Europe, 1914-1948, New York 2009. 
Despite some doubts on the actual shapes of parliamentarism outside England, ${ }^{4}$ the following is still considered an added value of parliamentarism worldwide: (i.) more direct responsibility towards citizens (electoral principle), (ii.) the potential to maintain responsible executive power on an ongoing basis, and (iii.) openness of parliamentary negotiation, which should facilitate the identification of relevant impacts influencing the decisionmaking. ${ }^{5}$ According to some authors, parliamentarism is best defined by the fact that it is an attempt at rule through discussion: more important than the decision itself is to persuade the opponent. 6

The states of East-Central Europe (among them the Austro-Hungarian Empire in particular), attempted specifically after the series of bourgeois revolutions of $1848 / 49$, to emulate the parliamentary system created in England and by then already operating in France (the first attempt being the constitution of 1791, however, parliamentarism being finally fully introduced in France only in 1875). Especially the idea of parliamentary representation was thereby tempting for the bourgeoisie in this model, hoping to limit that way the absolute power of sovereign and of traditional aristocratic circles.

Hungary was also trying to implement the parliamentary system already in the second half of the 19th century - even the building of the Hungarian Parliament was supposed to indicate the English model. In the end of the day, however, the system introduced in Hungary was only an apparent parliamentarism without a general right to vote and with the preservation of power in the hands of rich landowners. Due to reluctance to introduce universal suffrage and continuing social division of Hungarian society, democratic parliamentarism in Hungary was never fully implemented until the disintegration of Austria-Hungary in $1918 .^{7}$

Slovak political figures, claiming to speak on behalf of one of the nations of multinational Hungarian Kingdom, in contrast, promoted the idea of universal suffrage and representative principle already in their political program of 1848 revolution, called Demands of the Slovak Nation. These ideas were to be promoted by the (first) Slovak National Council, created in Vienna (the capital of Austria and the seat of the ruler) in September 1848 as a revolutionary body of Slovaks, which even declared the independence of Slovakia and Slovaks from Hungary a few days thereafter. ${ }^{8}$

Despite the failure of these revolutionary plans, creation of an independent Slovak parliament was requested by Slovak political representatives consistently in their subsequent political programs, including the last one - the Memorandum of the Slovak Nation from 1861. However, actual parliamentarism only found its expression in the territory of Slovakia after

\footnotetext{
4 Sometimes one speaks of post-parliamentarist democracy, where important decisions are taken by political parties and interest groups outside the parliament. Parliament and democracy were closely connected only in the 20th century. Cf. KYSELA, Jan: Zákonodárství bez parlamentů: Delegace a substituce zákonodárné pravomoci, Praha 2006, 27.

5 Ibidem, 20.

6 Ibidem, 23.

7 Cf. BEŇA, Jozef - GÁBRIŠ, Tomáš: History of Law in Slovakia I (until 1918), Bratislava 2015.

8 GÁBRIŠ, Tomáš - PATAKYOVÁ, Mária: Slovakia: The right of nation, in: First fundamental rights documents in Europe, SUKSI, Markku - AGAPIOU-JOSEPHIDES, Kalliope - LEHNERS, Jean-Paul - NOWAK, Manfred (eds.), Cambridge 2015.
} 
1918, within the Czechoslovak Republic ${ }^{9}$ in the form of Czechoslovak National Assembly, consisting of two chambers. However, special Slovak parliament was not established even in the democratic Czechoslovakia, since the (second) Slovak national council re-established in 1918 to proclaim the will of Slovaks to join Czechoslovakia, was only short-lived and abolished in January 1919 by the Minister for Slovakia appointed by Prague government. ${ }^{10}$ Despite promises voiced in the Cleveland and Pittsburgh agreements signed by Czech and Slovak emigrants in the USA, Slovaks thus did not attain their own parliament until 1938. ${ }^{11}$ It was only in the tragic conditions of road to the Second World War ${ }^{12}$ that in Czechoslovakia Constitutional Act no. 299/1938 Coll. on Autonomy of Slovak Land of 22 November 1938 was enacted, which presupposed the creation of a Slovak national legislative body - the Diet of the Slovak Land, which was to be created on the basis of elections with a proportional system basically according to the principles of Act no. 126/1927 Coll. on elections to provincial and district assemblies. ${ }^{13}$ The Constitutional Act has exhaustively defined the competences of the National Assembly in Prague, while in all other matters, the Diet of the Slovak Land was competent to decide and act in the autonomous Slovak Land. ${ }^{14}$

The elections to the Diet were held on 18 December 1938. However, despite the original hopes, these were not democratic, pluralist elections. The list of candidates was firmly set as a single list and this list was supported by $90 \%$ of the votes. The Diet came together on 18 January 1939, and lasted until 1945 without any further renewal or legitimization through elections.

During the period of the Second World War, Nazi-sponsored Slovak State was proclaimed on 14 March 1939 in place of the autonomous Slovak Land, while the legislative power was further reserved to the Diet, identical with that of former the Slovak Land, only being legally renamed from the Diet of the Slovak Land to the Diet of the Slovak Republic. Since there were no elections to the Diet during the existence of the war-time Slovak State (19391945), the vacant seats were filled through appointment by the President of Republic. ${ }^{15}$ Thanks to the Slovak National Uprising of 1944, organized and directed by the (third) Slovak National Council, established in 1943 in Bratislava (by the so-called Christmas Agreement) as a representative body of civil and communist resistance, with the end of the Second World War, the Czechoslovak Republic was reunited and restored, winning the support of anti-fascist and anti-Nazi Slovak forces. Thereby, important for the history of parliamentarism and of the SNC is the fact that during the revolutionary times of Slovak National Uprising the SNC by its regulation no. 1/1944 seized all state power on the

9 Even in the interwar Czechoslovakia, heralded for its parliamentarism and democracy, there were visions of a establishing a parliament of estates or of professions, voiced mostly in 1930s. Cf. VAVŘínEK, František: Parlament a politické strany, Praha 1930, 39, 49.

10 HRONSKÝ, Marián: Vznik a činnost' druhej Slovenskej národnej rady (1918-1919), in: Slovenské národné rady, PEKNÍK, Miroslav (ed.), Bratislava 1998, 59-60, 66-70.

11 Disregarding an administrative assembly called land assembly, established in 1928/29.

12 Cf. ŠVECOVÁ, Adriana - GÁBRIŠ, Tomáš: Dejiny štátu, správy a súdnictva na Slovensku, Plzeň 2009 , 175.

13 VOJÁČEK, Ladislav - SCHELLE, Karel: Právní dějiny na území Slovenska, Ostrava 2008, 286.

14 Ibidem.

15 PODOLEC, Ondrej: Prvý slovenský parlament, Bratislava 2017. 
insurgent territory. According to the Regulation, "the SNC carries out the entire legislative, governmental and executive power in Slovakia." Any other normative power was thus excluded to operate in Slovakia, in the very beginning including the Czechoslovak bodies, until recognized by the SNC. Due to this historical fact, in the post-war Czechoslovakia, Czechoslovak government as well as the Czechoslovak president ( $E$. Beneš) were willynilly forced to recognize the power of the SNC in territory of Slovakia, while in turn, the SNC acknowledged the restoration of Czechoslovakia and the idea of uninterrupted international continuity of existence of Czechoslovakia, regarding the war-time period as legally non-existent from the international point of view. ${ }^{16}$

Thus, the SNC remained an important source of state power in Slovakia, only gradually giving up and transferring its competences to the central authorities of the Czechoslovak Republic. This was performed by a series of three Prague agreement. The so-called first Prague agreement between Prague government and the SNC came into force as of 2 June 1945. Subsequently, on 11 April 1946, the second Prague agreement was signed between Prague government and the SNC, further limiting the competences of the SNC. On the same day, the Constitutional Act no. 65/1946 Coll. on Constitutional Assembly was enacted, in which, for the very first time (!), the SNC was explicitly mentioned in a Czechoslovak text of constitutional relevance, previously being only accepted in the documents of political nature (such as the so-called Košice Governmental program of 5 April 1945).

The third Prague agreement, adopted within the so-called National Front (grouping of all political parties in Czechoslovakia) on 27 June 1946, again further limited the competences of the SNC, subordinating the SNC to the Czechoslovak government's preventive control, while subordinating its Board of Trustees as an executive body of the SNC to the Prague government, introducing at the same time parallel competences of the Trustees and the Prague ministers in the same matters for the territory of Slovakia. ${ }^{17}$ All the activity of the SNC was in the end of the day subordinated to preventive and posterior control of the Prague government and the Board of Trustees of SNC was in effect turned into an executive body of the Prague government. This, of course, eliminated any elements of federalism that might had been present up to that date in Czechoslovakia (resulting from the special position of the SNC as the exclusive source of state power in Slovakia since the entry into force of regulation no. 1/1944 and since the integration of the SNC into the system of Czechoslovak authorities in the first and second Prague agreements). Instead, an evidently asymmetric model of Czecho-Slovakia was established in 1946. ${ }^{18}$

16 BEŇA, Jozef: Vývoj slovenského právneho poriadku, Banská Bystrica 2001, 109-110, 126-127. See also BEŇA, Jozef: Abriss der Staats- und Rechtsgeschichte der Tschechoslowakei nach dem Zweiten Weltkrieg, in: Normdurchsetzung in Osteuropäischen Nachkriegsgesellschaften (1944-1989). Bd. 4 Tschechoslowakei (1944-1989), MOHNHAUPT, Heinz - SCHÖNFELDT, Hans-Andreas (eds.), Frankfurt am Main 1998, 447-476; PAVLÍČEK, Václav: Über die Dekrete des Präsidenten der Republik in der Kontinuität von Staat und Recht, in: Normdurchsetzung in Osteuropäischen Nachkriegsgesellschaften (1944-1989). Bd. 4 Tschechoslowakei (19441989), MOHNHAUPT, Heinz - SCHÖNFELDT, Hans-Andreas (eds.), Frankfurt am Main 1998, $23-76$.

17 On the Prague agreements, see KVETKO, Martin: Dohody o štátoprávnom usporiadaní pomeru Čechov a Slovákov v oslobodenej vlasti, Bratislava 1947.

18 On the hectic changes of 1945-1948, cf. MYANT, Martin: Socialism and Democracy in Czechoslovakia: 19451948, Cambridge 1981. 
Hence, since 1946, the position of the SNC as a parliament, embodying a sovereign of Slovakia, was largely degraded. After the third Prague agreement, there even occurred a clear reduction in normative production (legislative activity), while more than half of the published legal texts were only implementing regulations. ${ }^{19}$ However, the SNC still remained formally a part of the Czechoslovak constitutional system. According to the Constitution of 9 May 1948, the Slovak National Council was a 100-member assembly elected for 6 years. However, under the same Constitution, it was entitled to exercise legislative power only in very limited fields.

Finally, as for the mechanism of creation of the SNC, it is important to note that the SNC was elected neither during the wartime, nor after the war, nor after the enactment of Constitution in 1948. National Assembly elections on 30 May 1948, were only taken as a model upon which to supplement the SNC, while individual representatives were delegated by political parties represented in the SNC, which could withdraw their representatives from SNC at any time - a de facto imperative mandate was thus introduced for the SNC. ${ }^{20}$ Only on 28 November 28 1954, under the Act of the SNC no. 7/1954, finally the first general and direct elections to the SNC took place since its inception in 1943(!).

Important change in the position of Slovak national authorities took place soon. In 1956, the resolution of the Central Committee of the Communist Party of March 30 entrusted the political bureau of the Central Committee of the Communist Party to introduce measures increasing the powers of the Slovak national authorities and, similarly, of the regional and district committees. These issues were also addressed by the National Communist Party Conference, which was held on 11-15 June 1956. In the government's declaration, the increase in powers of the Slovak authorities was presented as a prerequisite for the success of planned development of economy and culture in Slovakia and as a further step to consolidate the unity of the Republic and to deepen the fraternal relations of the two nations. ${ }^{21}$ However, the impetus to adjust the position of the Slovak authorities in 1956 in fact did not stem from the fundamental need to change the position of the Slovaks and Slovak authorities, but rather from the necessity of internal stabilization of the state and regime after the critique of Stalinism voiced in mid 1950s in the USSR.

According to the respective Constitutional Act no. 33/1956 Coll. of 31 July 1956 on the Slovak National Authorities, the SNC was "the national authority of state power in Slovakia." In fact, this was to mean that it was essentially only an extended arm of the unified state power seated in Prague. As regards the relationship with the executive power, the SNC has already in the war-time period created its Board of Trustees, which was considered the national authority of executive power in Slovakia even under the 1956 Constitutional Act. However, as soon as the shock from the horrors of Stalinism disappeared, Czechoslovak Communist Party leaders once again reinforced the centralization of the Republic in its new Constitution of 11 July 1960. The new arrangement of the Slovak national authorities, which was reflected in this Constitution, was thereby preceded by a political rationale approved by the political bureau of the Central Committee of the Communist Party already

19 BEŇA, Vývoj slovenského právneho poriadku, 282, 286.

20 BARNOVSKÝ, Michal: Slovenské národné orgány v čase vyvrcholenia mocenskopolitických zápasov (jeseň 1947 - február 1948), in: Slovenské národné rady, PEKNÍK, Miroslav (ed.), Bratislava 1998, 147.

21 BEŇA, Vývoj slovenského právneho poriadku, 333-334. 
on 23 February 1960. It states that the SNC should represent an integral part of the unified system of Czechoslovak state authorities. ${ }^{22}$ The state power was thus to be united, because under the socialist constitution of 1960, the Czechoslovak Socialist Republic was a single state of two equal fraternal nations, Czechs and Slovaks. In fact, however, the SNC did not fit into the system of state bodies at all, as it had no pendant in the Czech lands. It was clearly an asymmetric element, preserved only due to the role the SNC played in the Slovak National Uprising and in the re-establishment of Czechoslovakia after the Second World War. Nevertheless, the 1960 Constitution did not hesitate to intervene into the historical structure of the Slovak national authorities - abolishing the Board of Trustees completely. The SNC Presidency became the executive body of the SNC instead of the Board of Trustees. Thus, the SNC itself also embodied the unification of state power, meaning unification of legislative and executive powers, in the spirit of the Marxist-Leninist ideals.

Nevertheless, the legislative power of the SNC further on enshrined only the right to enact laws in matters of national and regional interest, and only under two conditions - (i.) insofar as the economic and cultural development of Slovakia required special arrangements, and (ii.) provided the laws were consistent with centrally enacted laws (in Prague). In addition, the SNC could adopt laws in matters as authorized by the National Assembly. In contrast to previous rules, the SNC has neither any more discussed and approved the national economy development plan nor discussed and approved the budget of Slovakia. Its role was defined only as participation in the preparation of the plan of national economy development. Such an arrangement was in line with the constitutional concept of Czechoslovakia as a unitary, centralized state with only formal recognition of Slovakia's autonomous status. Indeed, it was only a fictitious autonomy - albeit sections of state administration, which were transferred to the SNC competence, gradually expanded and the number of commissions underlying the authority of SNC also expanded, the unitary centralized nature of state power has been maintained all the time. ${ }^{23}$

After the federalization of Czechoslovakia in 1968/69, ${ }^{24}$ due to dissatisfaction of Slovak representatives with the abovementioned status of Slovak authorities, some changes were introduced - the SNC remained the representative of the national sovereignty and independence of the Slovak nation, being considered the supreme state authority in the Slovak Socialist Republic. As its pendant, the Czech National Council was established in the Czech lands. Thus, the asymmetric system has become a formally symmetric federation of two national republics.

The National Councils (the Czech one with 200 deputies and the Slovak one with 150 deputies) were elected for 4 years. However, the true Czech Socialist Republic, clearly distinguishable from the Czechoslovak Republic, was not accomplished. This was also reflected in the fact that the Czech National Council was first formed through elections

22 ŠTEFANSKÝ, Michal: Postavenie SNR v rokoch 1948-1967, in: Slovenské národné rady, PEKNÍK, Miroslav (ed.), Bratislava 1998, 156.

23 BEŇA, Vývoj slovenského právneho poriadku, 343-346, 353.

24 The only positive outcome of the process of democratization, during the so-called Prague Spring. Cf. McDERMOTT, Kevin: Communist Czechoslovakia: 1945-89: a political and social history, London 2015. 
by the Czechoslovak National Assembly itself (!). ${ }^{25}$ The system of two national councils and a bi-cameral Federal Assembly was then retained until the disintegration of Czechoslovakia. Important changes were introduced after November 1989, by the Constitutional Act no. 46/1990 Coll. adjusted anew the status of national authorities. The competences of the Federation and of Republics were redefined by Constitutional Act no. 556/1990 Coll. of 12 December 1990. The starting point for the redistribution of competences was the Constitutional Act on the Czechoslovak Federation of 1968. Still, unlike the 1968 model, listing of the exclusive competencies of the federation and of common (shared) competences has been omitted from the new text. Instead, the Constitutional Act was enumerating competences that belong to Federation, while the rest was attributed to the Republics. Unluckily, the result was that the unclear boundaries between competences of Federation and Republics as laid down in 1968, became even more obscured by the 1990 law. This has led to further disagreements and conflicts between the Republics on one hand and between Republics and Federation on the other, finally leading to the agreement on peaceful separation of the Federation into two independent Republics upon expiry of 31 December 1992. ${ }^{26}$

In connection with the extinction of the federation, the constitutional Act no. 205/1992 Coll. shortened term of office of the Federal Assembly as well as of national councils. Finally, as of 1 January 1993, with the independence of the Slovak Republic, the third and the last SNC in Slovak history (disregarding the emigrant councils established after 1945 abroad), existing continuously since 1943, was transformed into the exclusive legislative body of the newly established independent Slovak Republic, changing its official name to the National Council of the Slovak Republic.

\section{Analysis of parliamentarism in the Slovak territory between 1944 and 1992}

\section{Peculiarities of creation and legal basis of the SNC}

Based on the information provided in the first part of this paper, providing a general historical overview of the given period, we shall now move forward with a deeper analysis of the problems of Czechoslovak and Slovak parliamentarism of the 1944-1992 period. From the point of view of (un)implemented principles of parliamentarism in the territory of Slovakia in the period under review, we shall first focus here on the creation of SNC as a Slovak parliament.

Parliament is traditionally the most important representative body in a democratic state, given its competences - foremost representative and legislative. ${ }^{27}$ In general, the representative idea implements the concept of the sovereignty of the people, their power being transferred in elections to their elected representatives - members of the parliament.

25 BEŇA, Vývoj slovenského právneho poriadku, 360-361.

26 On details of the process, cf. SHEPHERD, Robin H. E.: Czechoslovakia: the Velvet Revolution and Beyond, London 2000.

27 Parliament was only the supreme representative body, on top of a pyramid of representative bodies formed at regional, district and local levels. 
By default, in the parliamentary system, the parliament as the highest representative body is formed in elections characterised by universal, equal, direct and secret ballot. However, the SNC was established in 1943 on the basis of the Christmas agreement of representatives of communist and non-communist (civil) resistance. It was thus not based on any elections of any sort. Similarly, after the outbreak of the Slovak National Uprising in August 1944, no direct elections were conceivable. SNC, deriving its legitimacy solely from revolutionary ideas, subsequently declared itself the supreme body of legislative, governmental and executive power in Slovakia (in its regulation no. 1/1944). Thus, in a revolutionary situation, at least two principles of modern parliamentarism were violated from a formal point of view - (i.) the SNC was not created in elections and (ii.) it was created as a single body of state power, logically without any "checks and balances" (although this was later amended by the subsequent regulations creating a Board of Trustees directly appointed by and responsible to the SNC). However, in a given revolutionary situation, it was certainly understandable. Due to the activities of the SNC during the uprising, the new Czechoslovak government, formed in 1945, was forced to recognize the equality of Czechs and Slovaks as two brotherly nations. The Slovak nation enjoyed since then a kind of autonomy in Czechoslovakia - albeit distorted by political centralism of the Communist Party of Czechoslovakia, which ruled in Czechoslovakia from 1948 to 1989. The manifestation and proof of this was preservation of the SNC as a state body with very limited competences for the territory of Slovakia in both post-war constitutions (1948 and 1960). However, its status was only that of "the national authority of state power in Slovakia." This meant that it was essentially an extended arm of the central partisan state power located in Prague. At the same time, show-trials with Slovak "bourgeois nationalists" in 1950s did not leave anyone in doubt about the impossibility of real independence of Slovak politics.

As far as the SNC proper is concerned, even after the war ended, the SNC's actual functioning was still based on the principle that members of the SNC were only appointed, until provisional indirect elections were held on 29 August 1945 in Banská Bystrica meaning indirect elections through local delegates.

Following the results of 1946 elections to the National Assembly, again, only a reconstruction of the SNC took place in 1946. Hence, still no proper direct elections to the SNC were held. Similarly, after the undemocratic parliamentary elections to the National Assembly in 1948 (with a uniform list of candidates presented by the Communist Party), ${ }^{28}$ the SNC was again merely supplemented according to the results of these elections. This unelected SNC then worked until 1954, when for the first time, "proper" elections to SNC finally took place. For this reason, it might be possible to question the legitimacy of the SNC as a representative of the sovereign Slovak nation until 1954. Moreover, the same doubts might also apply to the elections of 1954 which shared the same characteristics as were those of elections to the National Assembly already since 1948 - namely that the elections were understood rather as a plebiscite for the Communist Party's politics, than as a political struggle. ${ }^{29}$

This was confirmed also by other changes to the electoral system - when an imperative mandate was introduced, this did not mean a closer link with voters, but rather a closer link

28 Cf. KUKLíK, Jan: Czech Law in Historical Contexts, Praha 2015.

29 In 1986 elections, $99.95 \%$ voted for the candidates proposed by the National Front (in fact, Communist Party). 
to the Communist Party, ${ }^{30}$ and to the National Front which was the body proposing and drafting a list of candidates for the elections. The leading position of the Communist Party was even formally confirmed in the Constitution of the Czechoslovak Socialist Republic of 1960.

The new Czechoslovak Constitution, which was adopted in 1960 and proclaimed the "victory of socialism" in Czechoslovakia, did not reflect the need to change the position of the SNC. To the contrary, the abolition of the traditional Slovak executive body, the Board of Trustees, was an outcome of this Constitution. Nevertheless, the (non)existence of Slovak national bodies did not play any significant role in the functioning of the state anyway - due to the prevalence of the Party bureaucracy and the state bureaucracy over the parliament (be it the Czechoslovak National Assembly or the SNC). State power was vertically concentrated, with the centre in the Central Committee of the Communist Party. ${ }^{31}$ Art. 4 of the Constitution of 1960 unequivocally and unmistakably expressed the leading role of the Communist Party: "The leading force in society and in the state is the vanguard of the working class, the Communist Party of Czechoslovakia, the voluntary combat union of the most active and knowledgeable citizens of workers, peasants, and intelligence." The Czechoslovak parliament was only second-ranked on the ladder of importance, with the third-ranking position of the Slovak representative body (SNC) following.

It is therefore understandable that the democratization process of the 1960s, also associated with the rehabilitation of the so-called Slovak bourgeois nationalists ${ }^{32}$ and with new and more liberal reflections on the position of Slovakia and Slovaks in Czechoslovakia, led finally to a real attempt to the change their position within Czechoslovakia, which eventually led to the federalization of the Czechoslovak Socialist Republic in 1968.

The result was - after briefly considering other possible constitutional solutions - the Constitutional Act on the Czechoslovak Federation no. 143/1968, sometimes referred to as the "small constitution", which transformed the previously unitary statehood into triple statehood - Czech, Slovak, and Federal. The tasks related to the preparation of the arrangement were fulfilled by the Czech National Council and the SNC as national bodies of Czechs and Slovaks. However, the Czech National Council did not exist until then and it was established only in 1968 as a temporary body of constitutional political representation of the Czech nation. Its role was only and primarily to express the Czech political position on the future relations between the Czech and Slovak nations.

The Constitutional Act on Czechoslovak Federation ${ }^{33}$ was finally adopted on 27 October 1968 and officially signed on 30 October 1968, on the day of the $50^{\text {th }}$ anniversary of the St. Martin Declaration, by which the Slovak nation, as a "part of Czechoslovak nation", joined the Czechoslovak state in 1918.

According to the preamble to this Constitutional Act, the federalization was based on an

30 KYSELA, Zákonodárství bez parlamentů, 17.

31 PEŠKA, Pavel: Úvahy nad poprením ústavnosti v letech 1948-1989, in: Vývoj práva v Československu v letech 1945-1989: sborník príspěvků, MALÝ, Karel - SOUKUP, Ladislav (eds.), Praha 2004, 202-203, 206.

32 PEŠEK, Jan: Politický vývoj na Slovensku: od prevratu 1948 do prelomu rokov 1967/68, in: Rok 1968 a jeho miesto v našich dejinách, LONDÁK, Miroslav - SIKORA, Stanislav (eds.), Bratislava 2009, 32-38.

33 Cf. SIKORA, Stanislav: Československá jar 1968 a Slovensko, in: Rok 1968 a jeho miesto v našich dejinách, LONDÁK, Miroslav - SIKORA, Stanislav (eds.), Bratislava 2009, 82. 
agreement between the Slovak and Czech nations, which allegedly used and implemented their national sovereignty and the right to self-determination for the purpose of establishing a common federation. In reality, however, the whole process had taken the opposite direction - from top down. The unitary state had been transformed into a federation by the will of the Communist Party of Czechoslovakia, albeit at the same time it had also reflected the actual will of the Slovak nation and its call from "bottom up", but had not entirely reflected the will of the Czech nation, which was rather identified with the idea of unitary Czechoslovakia. The consequence was that although the previously asymmetric system with a sort of autonomy of Slovakia was transformed into a formally symmetrical federation of two national republics, the real Czech Socialist Republic, clearly distinguishable from the Czechoslovak federation, was never accomplished. In addition, the re-introduced centralization policy of the Communist Party and Government embarked upon as early as in 1969 (in reaction to military intervention of the Warsaw Pact countries in Czechoslovakia in 1968) soon centralized the executive power and also declared the state economy unified. ${ }^{34}$ Thus, in 1968/69, Slovaks have basically acquired only a formal statehood in the form of a member state of the Czechoslovak Federation. Still, this was a good starting point after the fall of the Communist Party's monopoly of power mere 20 years after the federalization - in 1989, when the SNC became an actual actor of the constitutional history of Slovakia.

The SNC might thus be regarded as a truly legitimate representative of the sovereign people - the Slovak nation - only after the first democratic and pluralist elections to the SNC in 1990. However, even prior to the 1990 elections, there was a rather peculiar transformation of the pre-1989 SNC taking place - similar to the situation in 1948, the development was marked by a "reconstruction" of the SNC: A number of SNC deputies namely gave up their functions, to be replaced by new deputies co-opted by the SNC itself to fill the vacant seats, ${ }^{35}$ which is not entirely in line with democratic standards and is rather a revolutionary situation. However, unlike in case of reconstructions in 1946 and 1948, in 1990, proper democratic elections followed quickly to confirm the democratic changes in the system and in the perception of parliamentarism.

\section{The peculiarities of SNC activity}

The basic division of parliaments in terms of their actual performed tasks and working methods is their division into debating, working and combined parliaments. ${ }^{36}$ The SNC activity initially appeared to be a combined, both debating and working parliament. In 1944-46, despite the unusual nature of its creation, the SNC namely had the powers of a standard representative body and fulfilled its tasks consequently.

However, the draft regulations were not presented to the SNC plenum by parliamentary committees, but rather by those Trustees (comparable to ministers) on whose behalf the relevant text was drafted. This might, according to some opinions, be seen as a sign

34 UHER, Ján: Slovenská národná rada v roku 1968, in: Slovenské národné rady, PEKNíK, Miroslav (ed.), Bratislava 1998, 185-186.

35 Under the constitutional act of 23 January 1990 on withdrawal of deputies from representative bodies and on election of new deputies.

36 KLOKOČKA, Vladimír: Ústavní systémy evropských států, Praha 2006, 341-342. 
of a "non-working" parliament. ${ }^{37}$ However, there was always a standard debate on the submitted proposals and not an automatic mechanism of their approval. In contrast to the situation in the National Assembly, the SNC members still presented amendments and changes to the drafts, some of which were accepted, and some rejected. However, since 1946, voting became often unanimous already in this period of history, e.g. the first Prague agreement was unanimously approved at the SNC meeting on 5 June 1945. By this agreement, as already mentioned, the SNC limited its own powers to the benefit of the central Prague authorities.

In the following period, the SNC obtained the confirmation of its legislative competence by the Constitution of 9 May 1948. However, after 1948, the nature of the SNC's activities changed substantively - due to its subordination to the Communist Party's policy. Although formally it was true that: "As for the composition of deputies of the Slovak National Council, 103 deputies are members of the Communist Party, 7 deputies of the Party of the Slovak Revival and 7 deputies of the Party of Freedom. 33 deputies are without political affiliation," in fact, the members of the SNC voted unanimously on all the proposals submitted by the Communist Party, and this was also reflected in the election of the SNC Presidency and the SNC Speaker.

The restoration of pluralism and independence within the parliamentary activities did not take place until 1989. Even shortly after the changes of 1989, surprisingly, there was still a seeming unity of opinion in the voting present, as a relic of the formalized parliamentary debate, evidenced by SNC member Trepáčs speech: "Whether we want to admit it or not, most of our citizens are accustomed to voting for whom they will be told, raising a hand, or throwing a paper with the name into the urn. This was also reflected in the recent elections of trade union or party officials. Elections were held a month ago, and today the removal of these officials is being sought." 38

In contrast, the resurfacing of the private initiative in parliamentary activity after 1989 was evident for example in the case of the establishment of a special commission for inquiry into police intervention in the candlelight demonstration of March 1988, or in creation of 12 working groups to draft bills on the right of assembly, association, press law and petition right, the law on political parties, the conscription law, the law on the territorial division of the Republic, on national committees (of local administration), on elections of the SNC and of the national committees, on the capital city Bratislava and on the regulation of the relationship between state and the Catholic Church. To express the opinions of SNC and its deputies, an institute of expressions and opinions was used-e.g. on expulsion of Slovak Germans after the Second World War, and similar. Thus, the character of the SNC was resumed again as being a combined, discussing and working parliament at once.

37 On working parliaments, cf. KYSELA, Zákonodárství bez parlamentů, 9.

$3817^{\text {th }}$ meeting of SNC on 30 November 1989.

Available at: https://www.nrsr.sk/dl/Browser/Document?documentld=10162 (10.11.2020). 


\section{Relationship between the SNC and executive power}

Parliaments are considered bearers of "completeness of power", 39 expressing the sovereignty of people and representing the supreme authority within a state. This characteristic fully applies to SNC in the insurgent period of 1944, when the SNC itself concentrated all power and was directly creating other state authorities, within a sort of "rule of parliament", different from traditional democratic parliamentary democracy. This situation has thereby heralded a later Marxist-Leninist theory of unified state power, denying any division of powers. This theory namely preaches refusal of separation of powers in favour of the idea of only a division of tasks among the supreme state authorities. In actual constitutional practice, the state authorities were namely supposed to cooperate, only formally being headed by the parliament as a representative of people's sovereignty. In fact, however, even the parliament was responsible to the working people, meaning to Communist Party: "the principle of the sovereignty of the working people means above all responsibility of all representative assemblies, the whole system of representative bodies, to the working people. But also - among other things - (for example, the responsibilities of executive bodies to representative bodies) the responsibility of all state authorities, including representative bodies to the Marxist-Leninist Party..." 40

Slovak national executive bodies, which were essentially the SNC Presidency (since 1960) and previously the Board of Trustees (until 1960), were thus under a triple subjection to the SNC, to working people and to the Party, whereby the Party control was of course the most relevant.

As part of its control competences towards the executive, the SNC had already known written interpellations to Trustees in 1945-46, but a significant restriction was introduced here in 1946-48. However, on 16 August 1946, the Board of Trustees was appointed only after the prior approval by the Czechoslovak Government of 14 August 1946, apparently meaning that the Board of Trustees was not to be understood solely as an executive body of the SNC, but rather it was also controlled by the Prague government. ${ }^{41}$

In this context a substantial change was introduced in 1948-54 in that the program of the Board of Trustees was to be approved by the SNC (for the first time at the 3rd SNC Plenary meeting on 29 July 1948). However, this is easily explained by the fact that the creation of the Board of Trustees was taken over by the Czechoslovak government on the basis of the Constitution of 9 May 1948. Since SNC was no longer involved in the creation of this body, it was given instead at least the opportunity to express the Trustees its confidence.

Return to the original concept from before 1948 occurred only in 1956 when the SNC was once again given the opportunity to appoint the Trustees; this approach was confirmed also upon the federalization of Czechoslovakia, when in the Slovak Socialist Republic arising in 1969, the SNC appointed the "government" of the Slovak Socialist Republic. The SNC was also to vote on the government's program, for an evaluation of which a special commission was set up, which was to draw up a resolution on the program and submitted it

39 PAVLÍČEK, Václav et al.: Ústavní právo a státověda II. Díl, Praha 2008, 216.

40 ZDOBINSKÝ, Stanislav - ZLATOPOLSKIJ, David L.: Ústavní systémy socialistických zemí, Praha 1988, 215.

41 Claiming that the Board of Trustees is a national as well as central body, being executive body of both Prague and Bratislava. 
for approval to the SNC plenum. Interestingly, the commission was in charge of evaluating the government's program, ${ }^{42}$ which interferes with the traditional view on separation of powers between legislative and executive powers. However, it is fully in line with the idea of mutual co-operation between the state bodies of a unified state power.

Even in this respect, however, one must not forget that the whole system worked only due to the dependence of all supreme bodies, including the SNC, on the Communist Party and on the National Front (grouping of all socialist organizations, headed by the Communist Party). Thus, in fact, it was the Party's rule and control, instead of the rule and control by SNC- which is a fundamental contradiction with any principles of parliamentarism and separation of powers.

The return to the standard democratic parliamentarism with the division of powers and the system of checks and balances did not take place until 1989, and in the Slovak conditions it fully materialized mainly after the entry into force of the Constitution of the Slovak Republic on 1 January 1993 - this Constitution namely finally introduced for the first time in the Slovak Republic the system of parliamentary democracy, with the proper separation of powers between the parliament (legislature), government (executive), the head of state (President of the Slovak Republic), and judiciary.

\section{Conclusion}

The present paper, after an initial historical overview of the legal development of parliamentary system in the territory of today's Slovak Republic, has analysed selected issues of the specific sort of parliamentarism existing in Slovakia under Communist Party rule, taking the example of supreme Slovak national representative body - the Slovak National Council - within Czechoslovakia. It was created as a private body of resistance in 1943, while in the circumstances of the Uprising of 1944 it took over all legislative, governmental and executive power in Slovakia. Despite such a dominant position (gradually restricted by three so-called Prague agreements between 1945 and 1946), until 1954 this supreme authority of state power in Slovakia was not created in direct elections. Up to the Constitution of 1948 it even lacked a proper constitutional legal basis (only the constitutional act of 1945 on Provisional National Assembly took into account the existence of the SNC). And even when the very first direct elections in 1954 took place, these were already marked by a new understanding of the electoral struggle, where general, equal, direct elections with a secret ballot only served to confirm the dominance of the Communist Party on the political scene. The SNC therefore only became truly legitimate and democratic in the sense of the true embodiment of the will of the sovereign Slovak nation after 1989.

Based on the research on SNC's significance and activity in the period under review (1944-1992), it may be stated that SNC witnessed a gradual decrease in its activity and importance, both in quantitative terms (given the scope of competences and outputs of the activity in the form of enacted laws) and qualitative terms (given that submitted proposals were approved without comments and discussions). The decrease was reversed only in the conditions of Czechoslovak federation since 1969.

42 Cf. $2^{\text {nd }}$ meeting on 4 July 1986. 
In relation to executive power, the loss of control of SNC over its own executive body (Board of Trustees) in favour of Prague government can be specifically witnessed in 1940s and 1950s. In addition, the idea of a unified state power and its centralist execution influenced the relationship between the legislature and executive in the sense that these two components were to cooperate and not to control each other, since they were expected to pursue a common goal of construction of communism. This has caused that while cooperation was promoted on the one hand instead of control, on the other hand, this cooperation essentially entailed direct control and interference by the Communist Party.

The analysis of the respective (constitutional) legislation as well as of the stenographic records (protocols) from the SNC meetings thus clearly show that the SNC (and similarly the National Assembly, replaced by Federal Assembly) was in fact only executing the Party's orders, being neither a working, nor discussing parliament; and even rather than "parliament" being only a formal, seeming "legislative body".

\section{References}

BARNOVSKÝ, Michal: Slovenské národné orgány v čase vyvrcholenia mocenskopolitických zápasov (jeseň 1947 - február 1948), in: Slovenské národné rady, PEKNíK, Miroslav (ed.), Bratislava 1998, 147.

BEŇA, Jozef - GÁBRIŠ, Tomáš: History of Law in Slovakia I (until 1918), Bratislava 2015.

BEŇA, Jozef: Abriss der Staats- und Rechtsgeschichte der Tschechoslowakei nach dem Zweiten Weltkrieg, in: Normdurchsetzung in Osteuropäischen Nachkriegsgesellschaften (1944-1989). Bd. 4 Tschechoslowakei (1944-1989), MOHNHAUPT, Heinz - SCHÖNFELDT, Hans-Andreas (eds.), Frankfurt am Main 1998, 447-476.

BEŇA, Jozef: Vývoj slovenského právneho poriadku, Banská Bystrica 2001.

GÁBRIŠ, Tomáš - PATAKYOVÁ, Mária: Slovakia: The right of nation, in: First fundamental rights documents in Europe, SUKSI, Markku - AGAPIOU-JOSEPHIDES, Kalliope - LEHNERS, Jean-Paul - NOWAK, Manfred (eds.), Cambridge 2015.

HRONSKÝ, Marián: Vznik a činnost' druhej Slovenskej národnej rady (1918-1919), in: Slovenské národné rady, PEKNÍK, Miroslav (ed.), Bratislava 1998, 59-60, 66-70.

KLOKOČKA, Vladimír: Ústavní systémy evropských států, Praha 2006.

KUKLÍK, Jan: Czech Law in Historical Contexts, Praha 2015.

KVETKO, Martin: Dohody o štátoprávnom usporiadaní pomeru Čechov a Slovákov v oslobodenej vlasti, Bratislava 1947. 
KYSELA, Jan: Zákonodárství bez parlamentů: Delegace a substituce zákonodárné pravomoci, Praha 2006.

MCDERMOTT, Kevin: Communist Czechoslovakia: 1945-89: a political and social history, London 2015.

MYANT, Martin: Socialism and Democracy in Czechoslovakia: 1945-1948, Cambridge 1981.

ORZOFF, Andrea: Battle for the Castle: The Myth of Czechoslovakia in Europe, 1914-1948, New York 2009.

PAVLÍČEK, Václav et al.: Ústavní právo a státověda II. Díl, Praha 2008.

PAVLÍČEK, Václav: Über die Dekrete des Präsidenten der Republik in der Kontinuität von Staat und Recht, in: Normdurchsetzung in Osteuropäischen Nachkriegsgesellschaften (1944-1989). Bd. 4 Tschechoslowakei (1944-1989), MOHNHAUPT, Heinz - SCHÖNFELDT, Hans-Andreas (eds.), Frankfurt am Main 1998, 23-76.

PEŠEK, Jan: Politický vývoj na Slovensku: od prevratu 1948 do prelomu rokov 1967/68, in: Rok 1968 a jeho miesto $v$ našich dejinách, LONDÁK, Miroslav - SIKORA, Stanislav (eds.), Bratislava 2009, 32-38.

PEŠKA, Pavel: Úvahy nad popřením ústavnosti v letech 1948-1989, in: Vývoj práva $\checkmark$ Československu v letech 1945-1989: sborník příspěvků, MALÝ, Karel -SOUKUP, Ladislav (eds.), Praha 2004, 202-203, 206.

PODOLEC, Ondrej: Prvý slovenský parlament, Bratislava 2017.

SELINGER, William: Parliamentarism: From Burke to Weber, Cambridge 2019.

SHEPHERD, Robin H. E.: Czechoslovakia: the Velvet Revolution and Beyond, London 2000.

SIKORA, Stanislav: Československá jar 1968 a Slovensko, in: Rok 1968 a jeho miesto $v$ našich dejinách, LONDÁK, Miroslav - SIKORA, Stanislav (eds.), Bratislava 2009, 82.

ŠTEFANSKÝ, Michal: Postavenie SNR v rokoch 1948-1967, in: Slovenské národné rady, PEKNÍK, Miroslav (ed.), Bratislava 1998, 156.

ŠVECOVÁ, Adriana - GÁBRIŠ, Tomáš: Dejiny štátu, správy a súdnictva na Slovensku, Plzeň 2009.

UHER, Ján: Slovenská národná rada v roku 1968, in: Slovenské národné rady, PEKNÍK, Miroslav (ed.), Bratislava 1998, 185-186. 
VAVŘíNEK, František: Parlament a politické strany, Praha 1930.

VOJÁČEK, Ladislav - SCHELLE, Karel: Právní dějiny na území Slovenska, Ostrava 2008.

ZDOBINSKÝ, Stanislav - ZLATOPOLSKIJ, David L.: Ústavní systémy socialistických zemí, Praha 1988.

\section{Author}

prof. JUDr. PhDr. Tomáš Gábrišs, PhD., LLM, MA

Trnavská univerzita v Trnave, Právnická fakulta

Trnava University in Trnava, Faculty of Law

Hornopotočná 23, 91843 Trnava, Slovak Republic

tomas.gabris@truni.sk 